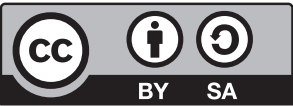

\title{
Nielegalność uzyskania dowodów w polskim procesie karnym Zagadnienia definicyjne
}

\begin{abstract}
The article is devoted to terminological issues pertaining to one of the most controversial problems in the Polish criminal proceedings which awakens keen interest of the legal doctrine. The author presents some fundamental definitional findings relating to such terms as: "illegal evidence", "the obtainment of illegal evidence", "directly illegal evidence", and "indirectly illegal evidence" based on various views expressed in this matter by the criminal procedure doctrine. While quoting the distinction into the directly illegal and indirectly illegal evidences, she postulates a more careful approach to defining the issues in question, which she substantiates by indicating Article 168 of the Code of Criminal Procedure. Resultantly, on the basis of assumed definitions of the two categories of illegal evidences, the author particularizes which of the two may constitute a ground for statements of fact and which needs to be further considered.
\end{abstract}

Keywords: evidence, illegal evidence, obtainment of evidence, directly illegal evidence, indirectly illegal evidence, fruit of the poisonous tree

\section{Wprowadzenie}

Artykuł stanowi próbę zdefiniowania podstawowych zagadnień w kontekście problematyki nielegalności uzyskania dowodów na gruncie polskiego procesu karnego. Należy wziąć pod uwagę to, że - w przeciwieństwie do kwestii dopuszczalności dowodów nielegalnych i możliwości ich wykorzystania w postępowaniu karnym - literatura poświęcona analizie polskiej doktryny karnoprocesowej natury terminologicznej związana z tytułowym zagadnieniem jest niezwykle uboga. Wydaje się jednak, że tylko po dokonaniu fundamentalnych ustaleń definicyjnych możliwe bę- 
dzie podjęcie rzetelnej refleksji nad budzącym niemało kontrowersji problemem dopuszczalności dowodów bezpośrednio nielegalnych i pośrednio nielegalnych. Zdając sobie sprawę z wagi tej materii w kontekście aktualnego brzmienia art. 168a k.p.k. ${ }^{1}$, w przedstawionych rozważaniach starano się ukazać, że znaczenie pojęć: ,„dowód nielegalny”, ,uzyskanie dowodów nielegalnych” czy „dowód bezpośrednio nielegalny” oraz „dowód pośrednio nielegalny" nie jest oczywiste, a zatem wymaga komentarza. Należy podkreślić, że dowód bezpośrednio nielegalny, w zgodzie z obecnym kształtem regulacji art. 168a k.p.k., jest co do zasady dopuszczalny w polskim procesie karnym ${ }^{2}$ i że Kodeks postępowania karnego nie zawiera ani zakazu, ani uprawnienia do wykorzystania w procesie karnym dowodu pośrednio nielegalnego. Ścisłe zdefiniowanie obu kategorii nie-

${ }^{1}$ Ustawa z dnia 6 czerwca 1997 r. - Kodeks postępowania karnego. Dz.U. 2021, poz. 534 , ze zm.

${ }^{2}$ Regulacja art. 168a k.p.k. co do zasady wprowadza generalną dopuszczalność dowodu uzyskanego z naruszeniem przepisów postępowania lub za pomocą czynu zabronionego $\mathrm{z}$ art. $1 \S 1$ k.k. Przywołane sformułowanie „naruszenie przepisów postępowania” dotyczy w praktyce większej liczby przypadków, gdy to wadliwość uzyskanego dowodu wynika z niewłaściwego działania funkcjonariuszy publicznych. Z kolei sformułowanie „czyn zabroniony z art. $1 \S 1$ k.k.” obejmuje swoim zakresem także dowody uzyskane za pomocą czynności pozaprocesowych przez inne osoby, w tym osoby prywatne, których przepisy postępowania dotyczące pozyskiwania dowodów bezpośrednio nie wiążą. Dokonana przez Jerzego Skorupkę interpretacja art. 168a k.p.k. (J. SKORUPKA: Prokonstytucyjna wykładnia przepisów prawa dowodowego $w$ procesie karnym. W: Verba volant, scripta manent. Proces karny, prawo karne skarbowe i prawo wykroczeń po zmianach z lat 2015-2016. Ksiega pamiatkowa poświęcona Profesor Monice Zbrojewskiej. Red. T. GrzegorczyK, R. Olszewski. Warszawa 2017, s. 362; identyczna interpretacja przepisu: Wyrok Sądu Apelacyjnego we Wrocławiu z dnia 22 listopada 2017 r. II AKa 224/17, LEX nr 2464913) wskazuje zaś, że w omawianym przepisie zakazem dowodowym objęte są jednak cztery „,kategorie dowodów: 1) dowód uzyskany z naruszeniem przepisów postępowania w związku z pełnieniem przez funkcjonariusza publicznego obowiązków służbowych; 2) dowód uzyskany za pomocą czynu zabronionego, o którym mowa w art. 1 \$ 1 k.k., w związku z pełnieniem przez funkcjonariusza publicznego obowiązków służbowych; 3) dowód uzyskany za pomocą czynu zabronionego, o którym mowa $\mathrm{w}$ art. 1 § 1 k.k., oraz z naruszeniem przepisów postępowania $\mathrm{w}$ związku z pełnieniem przez funkcjonariusza publicznego obowiązków służbowych; 4) dowód uzyskany za pomocą czynu zabronionego, o którym mowa w art. 1 $\S 1$ k.k., w wyniku: zabójstwa, umyślnego spowodowania uszczerbku na zdrowiu lub pozbawienia wolności”. Idąc więc w ślad za Dagmarą Gruszecką (D. GruszecKa: W kwestii interpretacji znowelizowanego przepisu art. 168a k.p.k. „Palestra” 2017, nr 1-2, s. 72, 75), która w identyczny sposób jak Skorupka dookreśla kategorie dowodów skażonych objętych zakazem dowodowym z art. 168a k.p.k., należy wyróżnić dwa różne standardy ochrony przed wprowadzaniem do procesu karnego dowodów nielegalnych. Pierwszy z nich odnosi się do dowodów uzyskanych wyłącznie przez funkcjonariuszy publicznych i to pod dodatkowym warunkiem zachowania związku z pełnieniem obowiązków służbowych, a drugi dotyczy już kwalifikowanego zachowania każdego innego podmiotu, obejmując m.in. obszar tzw. prywatnego pozyskiwania dowodów przez strony nieinstytucjonalne. 
legalności ma więc kluczowe znaczenie dla sprecyzowania, które dowody $\mathrm{z}$ pewnością de lege lata mogą być podstawą ustaleń dotyczących winy oskarżonego, a które z nich wciąż otwierają pole do dyskusji.

\section{Pojęcie dowodu nielegalnego}

„Proces karny to walka o dowody”3. Proces karny to też gra tymi dowodami pomiędzy stronami spierającymi się na różnych etapach jego przebiegu, umożliwia uzyskanie na podstawie dowodów odpowiedzi na pytanie, czy zostało popełnione przestępstwo i kto jest jego sprawcą ${ }^{4}$. Proces karny to poszukiwanie, zbieranie, utrwalanie, wprowadzanie do niego i przeprowadzanie dowodów przed organem procesowym, który będzie rozstrzygał o losie oskarżonego. To właśnie ze względu na osiągnięcie głównego celu procesu karnego, jakim jest rozstrzygnięcie o jego przedmiocie, dowody odgrywają priorytetową rolę. W nauce prawa dowodowego, zarówno polskiego, jak i obcego, pojęcie dowodu nie jest jednak pojmowane jednolicie. W doktrynie zauważa się, że nie ma w teorii procesu karnego bardziej wieloznacznego terminu ${ }^{5}$. Nazwa ta występuje w Kodeksie postępowania karnego w wielu przepisach, jednakże Kodeks nie zawiera jej definicji legalnej. W dogmatyce prawa karnego procesowego pojęcie dowodu jest sporne, co więcej, w poszczególnych działach Kodeksu jest ono używane w różnych znaczeniach, co wprowadza jeszcze większą dezorientację w próbie jego zdefiniowania. W większości przypadków zgodnie za dowód przyjmuje się „,rzecz lub argument, które o czymś świadczą, dowodzą czegoś” ${ }^{6}$ czy też „rzecz, sytuację, wydarzenie świadczące o czymś, wskazujące na coś"7.

Powszechnie przyjmowane znaczenie pojęcia dowodu w literaturze procesu karnego sprowadza się do przebiegu rozumowania, które prowadzi do sądu o określonym stanie rzeczy, stwarzającym pewność, zmie-

3 S. Waltoś: Owoce zatrutego drzewa. Kraków 2010, s. 231.

${ }^{4}$ Ł. CORA: Ryzyko nadużycia prawa karnego procesowego a granice realizacji funkcji ścigania - art. 168 a k.p.k. W: Proces karny $w$ dobie przemian. Zagadnienia ogólne. Red. S. STEInBorn, K. WoźnIEWSKI. Gdańsk 2018, s. 370.

5 Tak też: M. CIEśLAK: Zagadnienia dowodowe $w$ procesie karnym. W: IDEM: Dzieła wybrane. T. 1. Red. S. Waltoś. Kraków 2011, s. 35; S. Waltoś, P. Hofmański: Proces karny. Zarys systemu. Warszawa 2018, s. 353; W. JasińsкI: Nielegalnie uzyskane dowody w procesie karnym. W poszukiwaniu optymalnego rozwiazania. Warszawa 2019, s. 28; M. ZIELIŃski: Poznanie sadowe a poznanie naukowe. Poznań 1979, s. 47.

${ }^{6}$ Praktyczny słownik współczesnej polszczyzny. T. 9. Red. H. ZgóŁKowa. Poznań 1996, s. 220.

${ }^{7}$ Nowy słownik języka polskiego. Red. B. DunaJ. Warszawa 2007, s. 104. 
rzająca z kolei do ustalenia prawdy rzeczywistej. ${ }^{8}$ Inna definicja dowodu opisuje go jako wszystko to, co przyczynia się do wyjaśnienia prawdy w procesie karnym ${ }^{9}$. Trafnie wskazuje się również, że dowodem jest każdy dopuszczalny przez prawo karne procesowe środek służący dokonaniu prawdziwych ustaleń, dotyczących tych okoliczności, które mają znaczenie dla rozstrzygnięcia pewnej sprawy ${ }^{10}$. Wszystkie przywołane definicje opierają się na zasadzie prawdy jako naczelnej zasadzie procesu karnego. Dążenie do prawdy odgrywa bowiem kluczową rolę w aspekcie ostatecznego wyniku procesu myślowego ukształtowanego na podstawie dowodów, który doprowadzi do ustalenia, czy dany czyn miał miejsce, czy stanowi przestępstwo oraz kto będzie ponosić za niego odpowiedzialność karną.

Prima vista mogłoby się wydawać, że pojęcie dowodu nielegalnego zawiera wewnętrzną sprzeczność. Zaakcentowanie we wspomnianych definicjach faktu, że dowodem jest tylko to, co jest prawnie dozwolone, a jednocześnie tworzy przekonanie sądu o winie bądź braku winy oskarżonego, prowadzi do wniosku, że eliminuje się z zakresu tego pojęcia dowody uzyskane $\mathrm{w}$ sposób sprzeczny z prawem ${ }^{11}$. Refleksja nad pojęciem prowadzi jednak w pierwszej kolejności do wniosku, że brak jest jakiejkolwiek jego definicji legalnej. W Kodeksie postępowania karnego z 1997 r., podobnie zresztą jak w kodyfikacjach z 1928 r. i 1969 r., ustawodawca nie posługuje się terminem ,dowód nielegalny”. Z pozoru mogłoby się wydawać, że sprawa jest oczywista, a mianowicie chodzi o dowód, który uzyskano z naruszeniem prawa. Przy bliższym jednak spojrzeniu na omawianą materię odsłania się wieloznaczność i złożoność znaczenia tych słów ${ }^{12}$. Według Andrzeja Gaberlego dowodem nielegalnym jest „,każdy dowód uzyskany niezgodnie z warunkami jego uzyskania"13. Paweł M. Lech definiuje go jako dowód zgromadzony w konsekwencji działań naruszających prawo ${ }^{14}$, a Małgorzata Żbikowska pisze, że jest nim dowód uzyskany w wyniku przeprowadzenia czynności dowodowej w spo-

8 S. ŚLIWIŃski: Polski proces karny przed sądem powszechnym. Zasady ogólne. Warszawa 1948, s. 574.

${ }^{9}$ P. HofmańsKi, S. ZabŁOcKI: Elementy metodyki pracy sędziego $w$ sprawach karnych. Kraków 2006, s. 139.

10 T. GregorczyK, J. Tylman: Polskie postępowanie karne. Warszawa 2014, s. 464.

11 R.A. Stefański: Dowód nielegalny $w$ postępowaniu karnym. W: Proces karny $w$ dobie przemian. Zagadnienia ogólne. Red. S. STEINBORN, K. WoźnIEWsKI. Gdańsk 2018, s. 339.

12 W. JasińsKi, w: System prawa karnego procesowego. Red. P. HofmańsKi. T. 8: Dowody. Cz. 2. Red. J. SkorupKa. Warszawa 2019, s. 2329.

13 A. GABERLE: Dowody $w$ sadowym procesie karnym. Warszawa 2010, s. 383.

${ }_{14}$ P.M. Lech: Owoce zatrutego drzewa $w$ procesie karnym. Dowody zdobyte nielegalnie. „Palestra” 2012, nr 3-4, s. 35. 
sób nielegalny ${ }^{15}$. Dużo uwagi poświęca wskazanemu problemowi Jerzy Skorupka, akcentując różnicę w znaczeniu terminów „,dowód nielegalny" i „dowód uzyskany w sposób sprzeczny z ustawą"16. Zdecydowana większość przedstawicieli doktryny skupia się jednak raczej na kwestii dopuszczalności dowodów nielegalnych w procesie karnym i możliwości ich wykorzystania aniżeli na analizie tego, jaki zakres znaczeniowy przypisać omawianemu pojęciu. I choć można przyjąć, że dopuszczenie i wykorzystanie dowodów nielegalnych sprawia, że dowody uzyskane w sposób sprzeczny z prawem stają się dowodami w procesie karnym, to bez cienia wątpliwości nie łączy się tego z automatycznym uznaniem ich za dowody legalne.

Wieloznaczność pojęcia dowodu w kontekście problematyki nielegalności uzyskania dowodów rodzi więc pytanie: czy pojęcie dowodu używane jest zawsze w znaczeniu dowodu procesowego czy też chodzi o informacje, które mogą stać się dopiero w przyszłości dowodem procesowym? Analizowana tematyka wymaga wysunięcia na pierwszy plan konieczności dwojakiego posługiwania się słowem „dowód”. Już Paweł Horoszowski, na gruncie Kodeksu postępowania karnego z 1928 r., proponował zerwanie ze stosowaniem jednego terminu „dowód” na określenie tak wielu różniących się zasadniczo od siebie pojęć ${ }^{17}$. Należy wyróżnić znaczenie potoczne oraz procesowe dowodów ${ }^{18}$.

W zgodzie z pierwszym znaczeniem będą to informacje, które mają potencjalną użyteczność dla toczącego się postępowania karnego, dające możliwość ustalenia istotnych okoliczności $\mathrm{w}$ danej sprawie. Jest to pewna wiedza podmiotu poznającego, która może dopiero w przyszłości przybrać postać dowodu w znaczeniu dowodu procesowego, czyli w istocie dowodu dopuszczalnego w postępowaniu karnym. Jednak to, czy do tego dojdzie, jest uzależnione od spełnienia określonych warunków stawianych przez przepisy karnoprocesowe. Natomiast w drugim znaczeniu mowa o dowodzie w sensie procesowym, uzyskanym już na mocy przepisów prawa karnego procesowego. Oddzielenie od siebie dwóch wskazanych znaczeń nie zmienia jednak tego, że w języku prawniczym brakuje konsekwencji w ich rozróżnianiu, a widać to już na gruncie obowiązu-

15 M. Żвікошsка: Dowód pośrednio nielegalny w polskim procesie karnym. „Wojskowy Przegląd Prawniczy" 2012, nr 1-2, s. 108.

16 J. SKORUPKA: Eliminowanie z procesu karnego dowodu zebranego $w$ sposób sprzeczny z ustawa. „Państwo i Prawo” 2011, nr 3, s. 80-81; IDEm: Podstawy i tryb eliminowania $z$ procesu karnego dowodów uzyskanych $w$ sposób sprzeczny z ustawa. W: XX-lecie Sadu Apelacyjnego we Wrocławiu. Praca zbiorowa. Wrocław 2011, s. 322-327.

17 P. Horoszowski: Nazwa i pojęcie „dowodu” $w$ teorii $i$ praktyce prawa sądowego. „Państwo i Prawo” 1956, nr 10, s. 598.

18 W. JAsIŃsKI: Nielegalnie..., s. 34-35. 
jącego Kodeksu postępowania karnego. Oczywiste jest to, że w Kodeksie termin „dowód” występuje w znaczeniu procesowym, jednakże można wskazać na przepisy odnoszące się tylko i wyłącznie do informacji potencjalnie przydatnych dla celów postępowania. Dla przykładu taką regulacją jest art. $185 \mathrm{c} \S 1$ k.p.k., który stanowi, że w sprawach o przestępstwa określone w art. 197-199 k.k. zawiadomienie o przestępstwie, jeżeli składa je pokrzywdzony, powinno ograniczyć się do wskazania najważniejszych faktów i dowodów. W przywołanym przepisie mowa więc o dowodach w znaczeniu potocznym, rozumianych jako informacje przekazane przez pokrzywdzonego, które będą ewentualnie mogły kiedyś przybrać kształt dowodu procesowego ${ }^{19}$. Dlatego też de lege ferenda należałoby wyraźnie rozróżnić te dwie materie, używając dwóch odmiennych określeń, a to przede wszystkim ze względu na rosnące znaczenie gromadzenia dowodów przez osoby prywatne czy za pomocą „nieformalnych” czynności operacyjno-rozpoznawczych ${ }^{20}$, które nie są przecież w większości ujęte w ramach regulacji kodeksowych. Fakt, iż jest to aktywność pozaprocesowa, nie oznacza, że jest ona irrelewantna dla przebiegu postępowania karnego. Ustalenie jasnych relacji między znaczeniem potocznym a procesowym pojęcia dowodu staję się niezbędne $\mathrm{z}$ racji dynamicznego rozwoju technologii oraz możliwości totalnej i tajnej inwigilacji jednostki.

Nawiązując do aktualnego brzmienia regulacji art. 168a k.p.k., jako przyzwolenia na korzystanie $\mathrm{w}$ ramach polskiego procesu karnego $\mathrm{z}$ dowodów nielegalnych, należy podkreślić, iż niezwykle ważne jest rozróżnianie kontrowersyjnego pojęcia dowodu nielegalnego $w$ jego dwóch znaczeniach. Co do zasady nielegalność oznacza sprzeczność z prawem, która jawi się jako nieakceptowana, podczas gdy omawiany przepis generalnie dopuszcza dowody nielegalne $\mathrm{w}$ znaczeniu procesowym, tj. uzyskane $\mathrm{z}$ naruszeniem przepisów postępowania przez funkcjonariuszy publicznych, oraz dowody nielegalne w znaczeniu potocznym, uzyskane za pomocą czynu zabronionego $\mathrm{z}$ art. $1 \S 1 \mathrm{k} . \mathrm{k}$. już nie tylko przez funkcjonariuszy publicznych, a przez każdy inny podmiot, w tym osoby prywatne. Zasadą w polskim procesie karnym jest więc dopuszczalność wykorzystania dowodów nielegalnych, niedopuszczalność zaś - ograniczona do jaskrawych przejawów nadużycia władzy przez funkcjonariuszy publicznych (dowód nielegalny w znaczeniu procesowym) oraz kwalifikowanego zachowania kogokolwiek (dowód nielegalny w znaczeniu potocznym) - jedynie wyjątkiem. Dokonanie definicyjnego podziału na dowody nie-

19 Ibidem.

20 D. SzumiŁo-Kulczycka: Czynności operacyjno-rozpoznawcze $i$ ich relacje do procesu karnego. Warszawa 2012, s. 332-333. 
legalne $\mathrm{w}$ znaczeniu procesowym oraz potocznym jest niezbędne, aby móc wyróżnić dwa standardy ochrony, w postaci zakazów dowodowych wywiedzionych $\mathrm{z}$ art. 168a k.p.k., przed nieograniczonym wprowadzaniem do procesu karnego dowodów nielegalnych.

\section{Pojęcie uzyskania dowodów nielegalnych}

Refleksja nad problemem nielegalności uzyskania dowodów wymaga następnie sprecyzowania znaczenia sformułowania „uzyskanie dowodów". Posłużenie się tym wyrażeniem oznacza w ogólności wejście w posiadanie pewnej wiedzy, informacji, które mogą okazać się przydatne do ustalenia faktów istotnych w postępowaniu karnym. Zdefiniować „uzyskanie dowodów” należy jako zespół czynności uczestników procesu karnego, a także osób spoza tej kategorii, mających na celu włączenie do tego procesu źródeł i środków dowodowych. Uzyskaniem będą więc wszystkie czynności organów władzy publicznej, jak również osób prywatnych, których celem jest pozyskanie wiedzy o określonym dowodzie. Należy zauważyć, że zarówno w polskiej, jak i w obcej doktrynie posługiwanie się jednolitym terminem „uzyskanie” na określenie innych pojęć bliskoznacznych jest powszechne ${ }^{21}$. Dla przykładu Skorupka, korzystając ze sformułowania „dowody uzyskane w sposób sprzeczny z ustawą”, ma na myśli również dowody przeprowadzone $\mathrm{w}$ taki sposób ${ }^{22}$. Podobnie Żbikowska definiuje uzyskanie dowodów na gruncie problematyki dowodów nielegalnych, sygnalizując, że nielegalność odnosi się nie tylko do sytuacji uzyskania dowodu z nielegalnego źródła (gdy dowodzenie było niedopuszczalne), ale również do sposobu pozyskania lub przeprowadzenia danego dowodu ${ }^{23}$. Kontekst problemu nielegalności uzyskania dowodów uwidacznia, że w zasadzie pojęcia uzyskania, pozyskania ${ }^{24}$, zebrania $^{25}$, gromadzenia ${ }^{26}$, przeprowadzenia ${ }^{27}$ można traktować jako synonimy.

Na kanwie omawianego problemu należy wysunąć na pierwszy plan dwojakiego rodzaju sytuacje praktyczne związane z rozumieniem sformu-

21 W. JAsIŃsKi: Nielegalnie..., s. 37, 47.

22 J. SKorupKa: Podstawy..., s. 322.

${ }_{23}$ M. Żвікоwsка: Dowód..., s. 108.

${ }^{24}$ S. SKuBISZ: Problematyka wykorzystania $w$ procesie karnym ,owoców zatrutego drzewa”. W: Nowa kodyfikacja prawa karnego. T. 8. Red. L. Bogunia. Wrocław 2001, s. 258.

25 J. SKorUPKa: Eliminowanie..., s. 80.

${ }^{26}$ Ł. JAGIEŁEOWICZ: Dowody nielegalne $w$ kontradyktoryjnym procesie karnym. W: Kontradyktoryjność w polskim procesie karnym. Red. P. WiLIŃsKI. Warszawa 2013, s. 325.

27 I. SEPIOŁO: Nieobowiązywanie doktryny „owoców zatrutego drzewa” a wytyczne ETPC. „Palestra” 2010, nr 9-10, s. 227. 
łowania „uzyskanie dowodów”. Różnica pomiędzy dwoma omówionymi poprzednio kategoriami znaczenia dowodów tkwi przede wszystkim w sposobie ich uzyskania. W doktrynie karnoprocesowej kładzie się akcent na różnicę między pozaprocesową aktywnością w zakresie gromadzenia dowodów a procesowym poszukiwaniem i wstępnym zabezpieczeniem dowodów. Termin „uzyskanie” w odniesieniu do potocznego znaczenia pojęcia dowodu będzie oznaczał wejście w posiadanie informacji potencjalnie istotnych dla toczącego się postępowania za pomocą czynności pozaprocesowych, a w wypadku drugiego znaczenia - za pomocą czynności procesowych. Te dwie kwestie należy wyraźnie rozróżnić. Dowody w znaczeniu potocznym są bowiem pozyskiwane pozakodeksowo przez osoby prywatne oraz $\mathrm{w}$ ramach czynności operacyjno-rozpoznawczych przez funkcjonariuszy publicznych, zaś dowody procesowe są pozyskiwane $\mathrm{w}$ procesie karnym $\mathrm{w}$ zgodzie $\mathrm{z}$ regulacjami Kodeksu postępowania karnego, tylko i wyłącznie przez funkcjonariuszy publicznych.

Pierwsza sytuacja dotyczy aktywności poznawczej, która niekoniecznie mieści się w ramach postępowania dowodowego, a także, co istotne, zasadniczo nie jest regulowana normami prawa karnego procesowego ${ }^{28}$. Termin „poznanie” pojmuje się bowiem co najmniej na dwa sposoby. „Po pierwsze - odnosi się go do samego procesu poznania, do zespołu czynności zmierzających do tego, by jakiś podmiot poznający uzyskał wiedzę o jakimś przedmiocie poznania (przedmiocie, na który poznanie jest skierowane). Po drugie - termin ten oznacza rezultat, efekt dokonywania czynności poznawczych, a więc uzyskaną dzięki tym czynnościom wiedzę" ${ }^{29}$. W ten sposób pozyskana wiedza z natury rzeczy sięga poza granice postępowania dowodowego uregulowanego w Kodeksie prowadzonego przed organami procesowymi. W omawianej sytuacji należy mieć na względzie przepisy innych dziedzin prawa, tj. ustawodawstwa policyjnego czy administracyjnego, w których gromadzenie informacji przez organy państwowe jest uregulowane. Z kolei do zbierania potencjalnego materiału dowodowego przez osoby prywatne odnoszą się także, choć oczywiście nie wyłącznie i nie wprost, przepisy określające prawa, obowiązki oraz zakazy skierowane do jednostek, w szczególności będzie to zatem materialne prawo karne. Gdy mowa więc o uzyskanych dowodach w znaczeniu potocznym, problematyka ta może sytuować się poza ramami toczącego się postępowania, a przepisy karnoprocesowe nie muszą jej w całości obejmować.

${ }^{28}$ R. KмIECIK: „Dowód prywatny” i tzw. zasada swobody dowodzenia w postępowaniu karnym. „Państwo i Prawo” 2013, nr 2, s. 34-37.

${ }^{29}$ M. Zieliński: Poznanie..., s. 29. 
Drugi aspekt omawianego sformułowania dotyczy gromadzenia dowodów już w toku danego procesu karnego. Należy mieć świadomość, że zagadnienia pozyskiwania, wprowadzania do procesu, przeprowadzania oraz oceny dowodu nie są regulowane przez ustawodawcę jednolicie. Nie budzi jednak wątpliwości, że dowodowe czynności poszukiwawcze (tj. zatrzymanie rzeczy, przeszukanie oraz kontrola i utrwalanie rozmów), w których wyniku możliwe jest pozyskanie dowodów przestępstwa, są kwestią stricte procesową. Normowane są przepisami prawa karnego procesowego, odbywają się już w toku postępowania karnego i zmierzają do realizacji jego celów. Poszukiwanie i wstępne zabezpieczenie dowodów przez organy procesowe stanowi pierwszy etap procesu dowodzenia. Dowodzenie to pewien modelowy łańcuch czynności ${ }^{30}$, w którym wyodrębnia się, oprócz przywołanego poszukiwania i zabezpieczania dowodów, również wprowadzanie, przeprowadzanie, ocenę dowodów oraz dokonywanie na ich podstawie ustaleń faktycznych. Co symptomatyczne, pierwszy etap procesu dowodzenia nie jest elementem każdego postępowania. Czynności te są fakultatywne i zachodzą w zależności od istniejącej sytuacji. Dla przykładu stają się zbędne, gdy określony dowód został wprowadzony do procesu na wniosek strony. Summa summarum uzyskiwanie i ujawnianie dowodów należy do obowiązków organów procesowych, a zwłaszcza tych, które są odpowiedzialne za prowadzenie postępowania przygotowawczego. Pozyskując dowody w znaczeniu procesowym, organy te są zobligowane do respektowania kodeksowych warunków dotyczących dowodowych czynności poszukiwawczych.

Zbieranie dowodów nie jest działalnością statyczną organów procesowych ani, w niektórych sytuacjach, organów pozaprocesowych czy osób prywatnych, podporządkowaną konkretnemu stadium postępowania. Ma ono charakter dynamiczny, a przykłady praktyki sądowej świadczą o tym, że kluczowy dowód może pojawić się nawet w postępowaniu odwoławczym $^{31}$. Zakres tematyczny uzyskania dowodów obejmuje zagadnienia zarówno czynności procesowych, odbywających się na podstawie Kodeksu postępowania karnego, jak i czynności pozaprocesowych, na które składa się rozbudowana regulacja czynności operacyjno-rozpoznawczych. Należy odnotować, że naruszenie prawa przy pozyskiwaniu dowodów, charakteryzowane jako sprzeczność między zachowaniem danego podmiotu a wzorem tego zachowania dekodowanym z obowiązujących regulacji prawnych, może mieć różną formę. Po pierwsze, może ono polegać na pogwałceniu przepisów o charakterze karnoprocesowym

30 R. Koper et al.: Proces karny. Red. J. Zagrodnik. Warszawa 2019, s. 370.

31 A. Drozd, w: System prawa karnego procesowego. Red. P. HofmańsKi. T. 8: Dowody. Cz. 3. Red. J. SKorupKa. Warszawa 2019, s. 3410. 
(umiejscowionych zarówno w ustawie karnoprocesowej, jak i poza nią). Po drugie, nielegalność może również oznaczać naruszenie innych przepisów prawnych, i to różnych gałęzi prawa (cywilnego, karnego, administracyjnego). Znamienne jest to, że jednym zachowaniem osoba, która zebrała dowód, może naruszyć więcej niż jeden przepis, co w konsekwencji może rodzić skutki na płaszczyźnie więcej niż jednej gałęzi prawa.

Podsumowując, sformułowanie „uzyskanie dowodów” powinno się rozumieć na dwa sposoby. W znaczeniu potocznym - jako wejście w posiadanie danej informacji przez zarówno organy państwowe, jak i osoby prywatne, przy czym pozyskanie jej nie musi być regulowane przepisami karnoprocesowymi i może dziać się poza procesem karnym, zaś w znaczeniu procesowym - jako zebranie dowodu przez organy władzy publicznej w toku czynności procesowych. De lege lata należy zaakcentować jednak doniosłość świadomości posługiwania się omawianym sformułowaniem w kontekście nielegalności, a to z uwagi na aktualnie obowiązujący przepis art. 168a k.p.k., zgodnie z którym nie można wykluczyć dowodu nielegalnego na tej tylko podstawie, że - nie będąc objęty zakazem dowodowym - został on uzyskany z naruszeniem przepisów postępowania lub za pomocą czynu zabronionego z art. $1 \S 1$ k.k.

\section{Pojęcie dowodów uzyskanych bezpośrednio i pośrednio nielegalnie}

W analizie pojęciowej dowodów bezpośrednio i pośrednio nielegalnych problem ich uzyskania sprowadza się do podstawowej kwestii, a mianowicie należy postawić pytanie: jak traktować sytuacje, w których $\mathrm{w}$ wyniku nielegalnego uzyskania dowodu organ procesowy lub inny podmiot uzyska informacje pozwalające na uzyskanie innego dowodu? Termin „uzyskanie” nie został tu trzykrotnie przywołany bezzasadnie. Odnosi się on bowiem zarówno do wejścia w posiadanie źródła dowodowego, jak i do przeprowadzenia danego dowodu w stosunku do obydwóch wskazanych przypadków. Nie ulega wątpliwości, że o ile w danej sytuacji stwierdzona zostanie nielegalność uzyskania dowodu, o tyle kolejnego dowodu, uzyskanego na jego podstawie, nie musi i najczęściej nie będzie owa nielegalność charakteryzować. Nie zmienia to jednak faktu, że jeśli oceniać omawianą materię globalnie, nielegalność uzyskania dowodów oznaczać będzie zachowanie sprzeczne z prawem. W związku z tym w doktrynie wprowadza się rozróżnienie na dowody uzyskane bezpośrednio nielegalnie oraz dowody uzyskane pośrednio nielegalnie i to nad tymi drugimi należy się $\mathrm{w}$ tym miejscu pochylić. Problematyka dowodów uzyskanych pośrednio nielegalnie zaliczana jest niewątpliwie do jednych z bardziej złożonych, zawiłych i kontrowersyjnych, dlatego też 
bliższe przyjrzenie się spotykanym w doktrynie definicjom omawianego pojęcia okazuje się niezwykle ważne.

Nielegalny jest dowód zdobyty niezgodnie z przepisami prawa, $\mathrm{tj}$. nielegalnie wytworzony (dowód bezpośrednio nielegalny, nielegalny pierwotnie), lecz można również przyjąć, że będzie nim i ten uzyskany $\mathrm{z}$ nielegalnego dowodu (dowód pośrednio nielegalny, nielegalny wtórnie $)^{32}$. Charakterystyka dowodu nielegalnego została już wcześniej przedstawiona i takie właśnie znaczenie nadać należy dowodowi bezpośrednio nielegalnemu. Z kolei definicje dowodu pośrednio nielegalnego lub też nazywanego pośrednio skażonym wskazują, że jest nim dowód „uzyskany w wyniku przeprowadzenia innego dowodu posiadającego przymiot dowodu nielegalnego (a zatem uzyskanego na skutek przeprowadzenia czynności dowodowej w sposób nielegalny), [...] bez którego ten pierwszy nie zostałby prawdopodobnie odnaleziony"33. Chodzi więc o dalszy dowód, o którym organ procesowy dowiedział się z tego nielegalnego ${ }^{34}$. Jest to dowód, który „udało się uzyskać tylko dzięki innemu, wcześniej przeprowadzonemu, nielegalnemu dowodowi" ${ }^{35}$. W doktrynie pojawia się nadto definicja, że jest to dowód, który „,został ujawniony dzięki dowodowi zakazanemu"36. Wreszcie wskazuje się, że dowód ten został uzyskany na gruncie informacji nielegalnej, a więc uzyskanej bezpośrednio w wyniku działań naruszających prawo ${ }^{37}$. Należy uwypuklić, że „dowodem pośrednio nielegalnym jest źródło lub środek dowodowy, którego uzyskanie było możliwe dzięki informacjom (środkom dowodowym $\mathrm{w}$ znaczeniu procesowym albo dowodom $\mathrm{w}$ znaczeniu pozaprocesowym) uzyskanym niezgodnie z prawem" ${ }^{38}$. Najprościej mówiąc, dowód uzyskany pośrednio nielegalnie jest wynikiem uzyskania innego dowodu, bezpośrednio nielegalnego. Sam nie jest uzyskany sprzecznie z prawem, ale źródło, z którego pochodzi, zostało zdobyte z naruszeniem przepisów prawa.

Dowody pośrednio nielegalne określane są powszechnie w języku prawniczym za pomocą metafory „owoce zatrutego drzewa”. Zasygnalizowania w tym miejscu wymaga jedynie, że „korzenie zatrutego drzewa”, jako koncepcja ukształtowana w porządku prawnym Stanów

32 R. STEFAŃsKi: Dowód..., s. 339-340.

33 M. Żвıкоwsка: Dowód..., s. 108.

34 Z. KwiatKowski: Zakazy dowodowe $w$ procesie karnym. Kraków 2005, s. 417; IDEM: Dopuszczalność wykorzystania dowodów „pośrednio nielegalnych” $w$ procesie karnym. „Problemy Prawa Karnego” 1995, z. 21, s. 74.

35 Z. SовоLEWSKI: Wartość nielegalnie uzyskanego dowodu $w$ postępowaniu karnym. „Annales Universitatis Mariae Curie-Skłodowska. Sectio G” 1976, nr 1, s. 51.

36 S. Waltoś: Owoce..., s. 231-277.

37 P. M. LECH: Owoce..., s. 35.

38 W. JAsIŃsKI: Nielegalnie..., s. 56. 
Zjednoczonych, wywarły kolosalny wpływ na dyskusję nad fenomenem dowodów nielegalnych. Amerykańska reguła wyłączenia dowodów odnosi się nie tylko do dowodów uzyskanych bezpośrednio poprzez naruszenie normy konstytucyjnej, gdyż Sąd Najwyższy Stanów Zjednoczonych rozszerzył jej stosowanie także na dowody uzyskane z dowodów uzyskanych nielegalnie. Nazywane są one mianem dowodów pośrednich (derivative evidence) oraz umownie "owocami zatrutego drzewa" (fruits of the poisonous tree $)^{39}$. W Polsce zaś po dodaniu do Kodeksu postępowania karnego art. 168a na mocy art. 1 pkt 52 Ustawy z dnia 27 września 2013 r. o zmianie ustawy - Kodeks postępowania karnego oraz niektórych innych ustaw $^{40}$ pojawiły się $\mathrm{w}$ doktrynie procesu karnego liczne głosy doszukujących się w nowym zakazie dowodowym podobieństw do założeń omawianej koncepcji. Dodany „wielką nowelizacją” Kodeksu postępowania karnego z 2013 r. art. 168a k.p.k. wszedł w życie 1 lipca 2015 r. Stanowiąc proceduralne novum, otworzył on rewolucyjny rozdział w dyskusji na temat problematyki dopuszczalności dowodów uzyskanych sprzecznie z prawem w systemie polskiego procesu karnego. W ogólnym ujęciu należy zaakcentować, że będąc w mocy tak krótko, art. 168a k.p.k. nie pozwolił na ukształtowanie orzecznictwa czy praktyki jego stosowania ani też na wyciągnięcie wniosków z optymalności jego kształtu, gdyż niedługo po jego wprowadzeniu został radykalnie zmieniony. Na mocy Ustawy z dnia 11 marca 2016 r. o zmianie ustawy - Kodeks postępowania karnego oraz niektórych innych ustaw ${ }^{41}$ treść art. 168a k.p.k., od 15 kwietnia 2016 r. do dziś, brzmi następująco: „dowodu nie można uznać za niedopuszczalny wyłącznie na tej podstawie, że został uzyskany z naruszeniem przepisów postępowania lub za pomocą czynu zabronionego, o którym mowa w art. 1 $\S 1$ k.k., chyba że dowód został uzyskany w związku z pełnieniem przez funkcjonariusza publicznego obowiązków służbowych, w wyniku: zabójstwa, umyślnego spowodowania uszczerbku na zdrowiu lub pozbawienia wolności”. Nie jest więc rzeczą zaskakującą brak jakiegokolwiek przepisu na gruncie Kodeksu postępowania karnego z 1997 r., podobnie jak w poprzednio obowiązujących kodyfikacjach karnoprocesowych, który wprost rozstrzygałby status dowodów pośrednio nielegalnych. Pomimo milczenia ustawodawcy w kwestii „owoców zatrutego drzewa” nie można narzekać na brak zainteresowania w literaturze czy orzecznictwie ich fenomenem. Wątpliwości budzi bowiem dopuszczalność zarówno dowodów

39 K. KRemens, w: System prawa karnego procesowego. Red. P. HofmańsKi. T. 8: Dowody. Cz. 1. Red. J. SkorupKa. Warszawa 2019, s. 1349.

${ }^{40}$ Ustawa z dnia 27 września 2013 r. o zmianie ustawy - Kodeks postępowania karnego oraz niektórych innych ustaw. Dz.U. 2013, poz. 1247.

${ }^{41}$ Ustawa z dnia 11 marca 2016 r. o zmianie ustawy - Kodeks postępowania karnego oraz niektórych innych ustaw. Dz.U. 2016, poz. 437, ze zm. 
bezpośrednio nielegalnych (w kontekście zasadności obecnego brzmienia art. 168a k.p.k.), jak i dowodów pośrednio nielegalnych (w kontekście braku w Kodeksie postępowania karnego zakazu wykorzystania takich dowodów, jak również zezwolenia na ich wykorzystanie).

Gdy mowa o dowodach pośrednio nielegalnych, na pierwszy plan wysuwa się wiążący się z nimi sztandarowy problem. Paradoks polega na tym, że są one uzyskane zgodnie z prawem, ale wiedza o ich istnieniu pozyskana została z naruszeniem prawa. Dlatego też problem dowodów nielegalnych obejmuje nie tylko te bezpośrednio pozyskane w sposób naruszający przepisy prawne. Niezwykle istotne znaczenie praktyczne mają także dowody uzyskane pośrednio nielegalnie. W tym kontekście należy podkreślić brak takiego samego jak w przypadku bezpośredniej nielegalności charakteru ich zebrania. Trzeba zwrócić uwagę na główną różnicę między omawianymi kategoriami dowodów nielegalnych. Dowód bezpośrednio nielegalny to dowód uzyskany w sposób sprzeczny z prawem, gdy za dowód pośrednio nielegalny uznajemy dowód wywodzący się z dowodu bezpośrednio nielegalnego. Innymi słowy, ten drugi jest pochodną dowodu bezpośrednio nielegalnego. Wejście w jego posiadanie byłoby niemożliwe, gdyby nie wcześniejsze naruszenie przepisów prawa. Co za tym idzie, sama czynność nosi znamiona legalności, jednak jej dokonanie nie odbyłoby się w danym miejscu i czasie bez wiedzy o dowodzie uzyskanym bezpośrednio nielegalnie. Traktując uzyskanie dowodów w oderwaniu od poprzednio dokonanych działań, a więc atomistycznie, należy zaakcentować, że dowody pośrednio nielegalne zostały pozyskane zgodnie z prawem. Przekonuje bowiem pogląd, że dowody te nie tracą na wiarygodności tylko z uwagi na nielegalne przeprowadzenie wcześniejszej czynności dowodowej ${ }^{42}$. Podsumowując, wadliwość dowodu pośrednio nielegalnego tkwi w źródle wiedzy o jego istnieniu, a więc fakcie gromadzenia informacji o tym dowodzie na podstawie innego dowodu, już bezpośrednio nielegalnego (w znaczeniu procesowym albo potocznym), pozyskanego za pomocą czynności procesowej lub pozaprocesowej.

W konkluzji poczynionych rozważań definicyjnych należy na zakończenie przenieść je na grunt obecnego kształtu art. 168a k.p.k. Wywodzona z przywołanego przepisu generalna dopuszczalność dowodów nielegalnych $\mathrm{w}$ polskim procesie karnym nabiera znaczenia przy wyróżnieniu dowodów bezpośrednio nielegalnych oraz dowodów pośrednio nielegalnych. To te pierwsze mogą obecnie stanowić podstawę dokonywania ustaleń faktycznych. Gdy mowa zaś o tych drugich, nie istnieje jeszcze

42 J. Michalsкi: Zakaz dowodowy z art. 168a k.p.k. a teoria „owoców zatrutego drzewa”. W: Dowód w procesie karnym w perspektywie porównawczej. Red. D. GIL. Lublin 2016 (Współczesne Problemy Wymiaru Sprawiedliwości. T. 6), s. 211. 
ostateczne, utrwalone i bezsporne stanowisko ani judykatury, ani doktryny w tym aspekcie. Należy jednak skonstatować, iż de lege lata brak jest regulacji prawnej, która wyraźnie eliminowałaby z ustaleń faktycznych dowody pośrednio nielegalne. Co do zasady wykorzystywanie w polskim procesie karnym „owoców zatrutego drzewa” jawi się jako akceptowane. Chcac, by prawo karne procesowe było skuteczne oraz by odpowiadało zasadzie trafnej reakcji karnej, z konieczności opowiedzieć się trzeba za ważeniem ad casu interesu państwa w ściganiu przestępstw i interesu jednostki przejawiającego się nienaruszaniem jej fundamentalnych praw i wolności. Brak wyraźnych regulacji odnoszących się do dowodów pośrednio nielegalnych przesuwa ciężar oceny możliwości ich wykorzystania na organy stosujące prawo, które to na potrzeby konkretnej sprawy mają dokonać kompleksowego badania okoliczności i interpretacji przepisów z uwzględnieniem zabiegu milczenia ustawodawcy $\mathrm{w}$ aspekcie dopuszczania tych dowodów.

\section{Podsumowanie}

Przedstawione rozważania jasno dowodzą, że możliwość procesowego wykorzystania dowodów bezpośrednio nielegalnych oraz pośrednio nielegalnych budzi zdecydowanie więcej zainteresowania doktryny karnoprocesowej oraz orzecznictwa sądów karnych aniżeli zagadnienia definicyjne ogniskujące się wokół sformułowania „nielegalność uzyskania dowodów”. Należy podkreślić, że ,problem sprzeczności dowodu z prawem jest niewątpliwie jednym z największych wyzwań nauki procesu karnego"43, dlatego też tak ważne jest dokonanie fundamentalnych ustaleń terminologicznych obejmujących zagadnienia dotyczące nielegalności uzyskania dowodów. Analizowane w tym artykule pojęcia stanowią bowiem punkt wyjścia do dyskusji i rzetelnej refleksji naukowej nad problematyką dopuszczalności dowodów nielegalnych w polskim procesie karnym. To wyraźne wyodrębnienie i ukazanie podstawowych różnic między dwoma kategoriami dowodów nielegalnych pozwala na ustalenie, że to dowody bezpośrednio nielegalne de lege lata są explicite uregulowane w art. 168a k.p.k. i co do zasady mogą stanowić podstawę ustaleń dotyczących winy oskarżonego lub jej braku (z wyjątkami na rzecz ich niedopuszczalności w postaci wywiedzionych z omawianego przepisu zakazów dowodowych). Z kolei dowody pośrednio nielegalne nie zostały

${ }^{43}$ D. SzumiŁo-KulczycKa: Wykorzystanie $w$ procesie karnym dowodów pochodzqcych z czynności pozaprocesowych policji i innych dziatajacych stużb - raporty krajowe. W: Pozaprocesowe pozyskiwanie dowodów i ich wykorzystanie $w$ procesie karnym. Red. P. Hofmański, D. SzumiŁo-Kulczycka, P. Czarnecki. Warszawa 2015, s. 57. 
przez ustawodawcę w Kodeksie postępowania karnego ani zakazane, ani też dopuszczone, co zaś, pomimo dominacji stanowiska o dopuszczalności ich wykorzystywania $\mathrm{w}$ procesie karnym, otwiera spektrum możliwości interpretacyjnych przed każdym prawnikiem zajmującym się tą materią.

\section{Bibliografia}

\section{Literatura}

CIEŚLAK M.: Zagadnienia dowodowe $w$ procesie karnym. W: IDEM: Dzieła wybrane. T. 1. Red. S. Waltoś. Kraków 2011.

CORA Ł.: Ryzyko nadużcia prawa karnego procesowego a granice realizacji funkcji ścigania - art. 168a k.p.k. W: Proces karny $w$ dobie przemian. Zagadnienia ogólne. Red. S. STEInborn, K. WoźNIEWSKi. Gdańsk 2018.

Drozd A., w: System prawa karnego procesowego. Red. P. Hofmański. T. 8: Dowody. Cz. 3. Red. J. SKoruPKa. Warszawa 2019.

GaberLe A.: Dowody w sqdowym procesie karnym. Warszawa 2010.

GregorczyK T., Tylman J.: Polskie postępowanie karne. Warszawa 2014.

GruszeCKa D.: W kwestii interpretacji znowelizowanego przepisu art. 168a k.p.k. „Palestra” 2017, nr 1-2.

HOFMAŃsKi P., ZABŁOCKI S.: Elementy metodyki pracy sędziego $w$ sprawach karnych. Kraków 2006.

Horoszowski P.: Nazwa i pojęcie „dowodu” $w$ teorii i praktyce prawa sqdowego. „Państwo i Prawo” 1956, nr 10.

JaGIEtŁOWICZ Ł.: Dowody nielegalne $w$ kontradyktoryjnym procesie karnym. W: Kontradyktoryjność $w$ polskim procesie karnym. Red. P. WiLIŃsKI. Warszawa 2013.

JasińsKi W., w: System prawa karnego procesowego. Red. P. HofMański. T. 8: Dowody. Cz. 2. Red. J. SKoruPKA. Warszawa 2019.

JasIŃsKI W.: Nielegalnie uzyskane dowody $w$ procesie karnym. W poszukiwaniu optymalnego rozwiazania. Warszawa 2019.

KMIECIK R.: „Dowód prywatny” i tzw. zasada swobody dowodzenia w postępowaniu karnym. „Państwo i Prawo” 2013, nr 2.

Koper R. et al.: Proces karny. Red. J. ZAGrodniK. Warszawa 2019.

Kremens K., w: System prawa karnego procesowego. Red. P. HofMańsKi. T. 8: Dowody. Cz. 1. Red. J. SkorupKa. Warszawa 2019.

KwiatKowski Z.: Dopuszczalność wykorzystania dowodów „pośrednio nielegalnych” $w$ procesie karnym. „Problemy Prawa Karnego” 1995, z. 21.

KWIATKOWsкi Z.: Zakazy dowodowe w procesie karnym. Kraków 2005.

LECH P.M.: Owoce zatrutego drzewa w procesie karnym. Dowody zdobyte nielegalnie. „Palestra” 2012, nr 3-4.

MichALSKI J.: Zakaz dowodowy z art. 168 a k.p.k. a teoria „owoców zatrutego drzewa". W: Dowód w procesie karnym w perspektywie porównawczej. Red. D. GIL. Lublin 2016 (Współczesne Problemy Wymiaru Sprawiedliwości. T. 6). 
Nowy słownik języka polskiego. Red. B. Dunaj. Warszawa 2007.

Praktyczny słownik współczesnej polszczyzny. T. 9. Red. H. ZgóŁKowa. Poznań 1996.

SEPIOŁo I.: Nieobowiazywanie doktryny „owoców zatrutego drzewa” a wytyczne ETPC. „Palestra” 2010, nr 9-10.

SKORUPKA J.: Eliminowanie z procesu karnego dowodu zebranego w sposób sprzeczny z ustawa. „Państwo i Prawo” 2011, nr 3.

SKORUPKA J.: Podstawy i tryb eliminowania z procesu karnego dowodów uzyskanych w sposób sprzeczny z ustawa. W: XX-lecie Sąu Apelacyjnego we Wrocławiu. Praca zbiorowa. Wrocław 2011.

SKorupKa J.: Prokonstytucyjna wykładnia przepisów prawa dowodowego $w$ procesie karnym. W: Verba volant, scripta manent. Proces karny, prawo karne skarbowe $i$ prawo wykroczeń po zmianach z lat 2015-2016. Ksiega pamiatkowa poświęcona Profesor Monice Zbrojewskiej. Red. T. GrzegorczyK, R. OlszewsKI. Warszawa 2017.

SKUBISZ S.: Problematyka wykorzystania w procesie karnym „owoców zatrutego drzewa". W: Nowa kodyfikacja prawa karnego. T. 8. Red. L. BoguniA. Wrocław 2001.

Soвоlewsкi Z.: Wartość nielegalnie uzyskanego dowodu $w$ postępowaniu karnym. „Annales Universitatis Mariae Curie-Skłodowska. Sectio G” 1976, nr 1.

Stefański R.A.: Dowód nielegalny $w$ postępowaniu karnym. W: Proces karny $w$ dobie przemian. Zagadnienia ogólne. Red. S. SteInborn, K. WoźNiEWSKI. Gdańsk 2018.

SzumiŁo-Kulczycka D.: Czynności operacyjno-rozpoznawcze i ich relacje do procesu karnego. Warszawa 2012.

SzumiŁo-KulczycKa D.: Wykorzystanie $w$ procesie karnym dowodów pochodzacych z czynności pozaprocesowych policji i innych działających służb - raporty krajowe. W: Pozaprocesowe pozyskiwanie dowodów i ich wykorzystanie w procesie karnym. Red. P. Hofmański, D. Szumito-Kulczycka, P. Czarnecki. Warszawa 2015.

ŚLIWIŃsKi S.: Polski proces karny przed sądem powszechnym. Zasady ogólne. Warszawa 1948.

Waltoś S.: Owoce zatrutego drzewa. Kraków 2010.

Waltoś S., Hofmański P.: Proces karny. Zarys systemu. Warszawa 2018.

ZIELIŃsKi M.: Poznanie sądowe a poznanie naukowe. Poznań 1979.

ŻBIKOWsKA M.: Dowód pośrednio nielegalny w polskim procesie karnym. „Wojskowy Przegląd Prawniczy" 2012, nr 1-2.

\section{Akty prawne}

Ustawa z dnia 6 czerwca 1997 r. - Kodeks postępowania karnego. Dz.U. 2021, poz. 534 , ze zm.

Ustawa z dnia 27 września 2013 r. o zmianie ustawy - Kodeks postępowania karnego oraz niektórych innych ustaw. Dz.U. 2013, poz. 1247.

Ustawa z dnia 11 marca 2016 r. o zmianie ustawy - Kodeks postępowania karnego oraz niektórych innych ustaw. Dz.U. 2016, poz. 437, ze zm. 